\title{
52. PETROCHEMISTRY OF BASALTS AND PLUTONIC ROCKS, LEG 37, DEEP SEA DRILLING PROJECT
}

\author{
Leonid Dmitriev, Institute of Geochemistry, \\ Academy of Sciences of the USSR, Moscow, USSR
}

\section{INTRODUCTION}

During Leg 37 oceanic basement was drilled at four sites $(332,333,334$, and 335$)$ on the west flank of the Mid-Atlantic Ridge at approximately $37^{\circ} \mathrm{N}$ latitude. This report deals with the basaltic rocks recovered from Hole 332B and with a plutonic sequence encountered at Site 334.

Hole $332 \mathrm{~B}$ was drilled about $30 \mathrm{~km}$ from the ridge crest in basement approximately $3.5 \mathrm{~m}$.y. old. This hole penetrated 583 meters of acoustic basement with approximately $20 \%$ recovery. The basaltic sequence was divided by the shipboard party into 11 lithologic units largely on the basis of phenocryst content.

At Site 334 a plutonic complex was encountered beneath approximately 50 meters of basalt. The complex is a layered sequence of gabbro, troctolite, and lherzolite about 67 meters thick. Numerous breccia zones consist of plutonic clasts set in a matrix of nannofossil chalk.

\section{BASALTIC ROCKS OF HOLE 332B}

Two hundred seventy-six analyses of fresh basalt with $\mathrm{CO}_{2}$ less than $1 \mathrm{wt} \%$ were selected from Table 10B, Chapter 2 (this volume?. These were plotted against depth, and paired correlations were calculated for the major oxides. A special computer program was used for the calculations which divided all analyses into two principal groups distinguished by different correlation trends among the major oxides. The differences between the two groups have been demonstrated to be statistically significant by A.V. Garanin (Institute of Geochemistry, USSR Academy of Sciences). Analytical differences between different laboratories (see Wright, this volume) are distinctly less than the differences between the two groups. The paired correlations are shown in Figure 1 (a-g) where the different analyses are identified by subbottom depth. These diagrams clearly show the existence of the two main magma types and provide evidence that the observed chemical variations are due chiefly to differentiation of these two types. Magma group 1 is characterized by high $\mathrm{MgO}$, relatively high total iron (FeO), and low $\mathrm{SiO}_{2}$ and $\mathrm{CaO} . \mathrm{TiO}_{2}$ and $\mathrm{Al}_{2} \mathrm{O}_{3}$ exhibit a positive correlation, but $\mathrm{MgO}$ has a negative correlation with all other oxides except $(\mathrm{FeO})$. The concentration of $(\mathrm{FeO})$ probably does not depend on $\mathrm{MgO}$ content.

Chemical variations in magma group 1 reflect fractionation and accumulation of olivine or olivine + spinel. Petrographically, these basalts range from coarsely phyric picrites to aphyric types.
Magma group 2 has relatively high concentrations of $\mathrm{SiO}_{2}$ and $\mathrm{CaO}$ and low $\mathrm{MgO}$ and $(\mathrm{FeO})$. Wide variations in $\mathrm{Al}_{2} \mathrm{O}_{3}, \mathrm{CaO}$, and especially $(\mathrm{FeO})$ and $\mathrm{TiO}_{2}$ characterize this group. In contrast to group 1 magmas, $\mathrm{TiO}_{2}$ and $\mathrm{Al}_{2} \mathrm{O}_{3}$ show a negative correlation and $(\mathrm{FeO})$ and $\mathrm{TiO}_{2}$ show a positive correlation (Figure If, $1 \mathrm{~g}$ ). The chemical variations within magma group 2 are probably related to plagioclase fractionation and accumulation.

Two subgtoups (2a and $2 \mathrm{~b}$ ) are recognized on the basis of chemistry and mineralogy. Group 2a magmas have higher concentrations of $\mathrm{SiO}_{2},(\mathrm{FeO})$, and $\mathrm{TiO}_{2}$ and lower $\mathrm{Al}_{2} \mathrm{O}_{3}$ and $\mathrm{CaO}$ than those of group $2 \mathrm{~b}$. Rocks of group $2 \mathrm{a}$ are aphyric or sparsely phyric with phenocryst assemblages plagioclase + olivine + clinopyroxene. Subgroup $2 \mathrm{~b}$ consists chiefly of coarsely plagioclase-phyric basalt.

The distribution of group 1 and group 2 magmas with depth is shown schematically in Figure 2, along with shipboard lithologic units and paleomagnetic units. It can be seen that there is generally a close correspondence between chemical type and lithologic and paleomagnetic units. There is also evidence for cyclic variations in magma chemistry. All of the rocks are belived to be related to two main eruptive cycles, I and II. Both cycles contain all three recognized magma groups, and consist of several subcycles generally beginning with magmas of group 1 and ending with magmas of group 2b. Only the last subcycle is represented completely; the others normally terminate with magmas of group 2a (Figure 2). The boundary between the two main cycles is marked by alteration of the basalts (high $\mathrm{CO}_{2}$ contents) and by interlayering of basalts and sediments at the end of the first cycle. Generally the thickness and abundance of sedimentary interbeds increase upward not only in the section as a whole, but also within individual cycles and subcycles.

In most of the cycles and subcycles the different magma types occur in discrete units. However, in the lower part of subcycle $\mathrm{I}_{2}$, group 1 and group 2a magmas are intimately interlayered. This "interlayered complex" is succeeded upward by magmas of group $2 b$ and appears to be part of a normal cycle.

In general the thickness of individual flows and the volume of lava in individual cycles appears to increase upward in the section.

Experimental petrology suggests that magmas of group 1 should form by partial melting of mantle material at depths of 40 to $60 \mathrm{~km}$ and magmas of group 2 should form at depths of about $20 \mathrm{~km}$. The frequent eruption of these two distinct magma types suggests a 


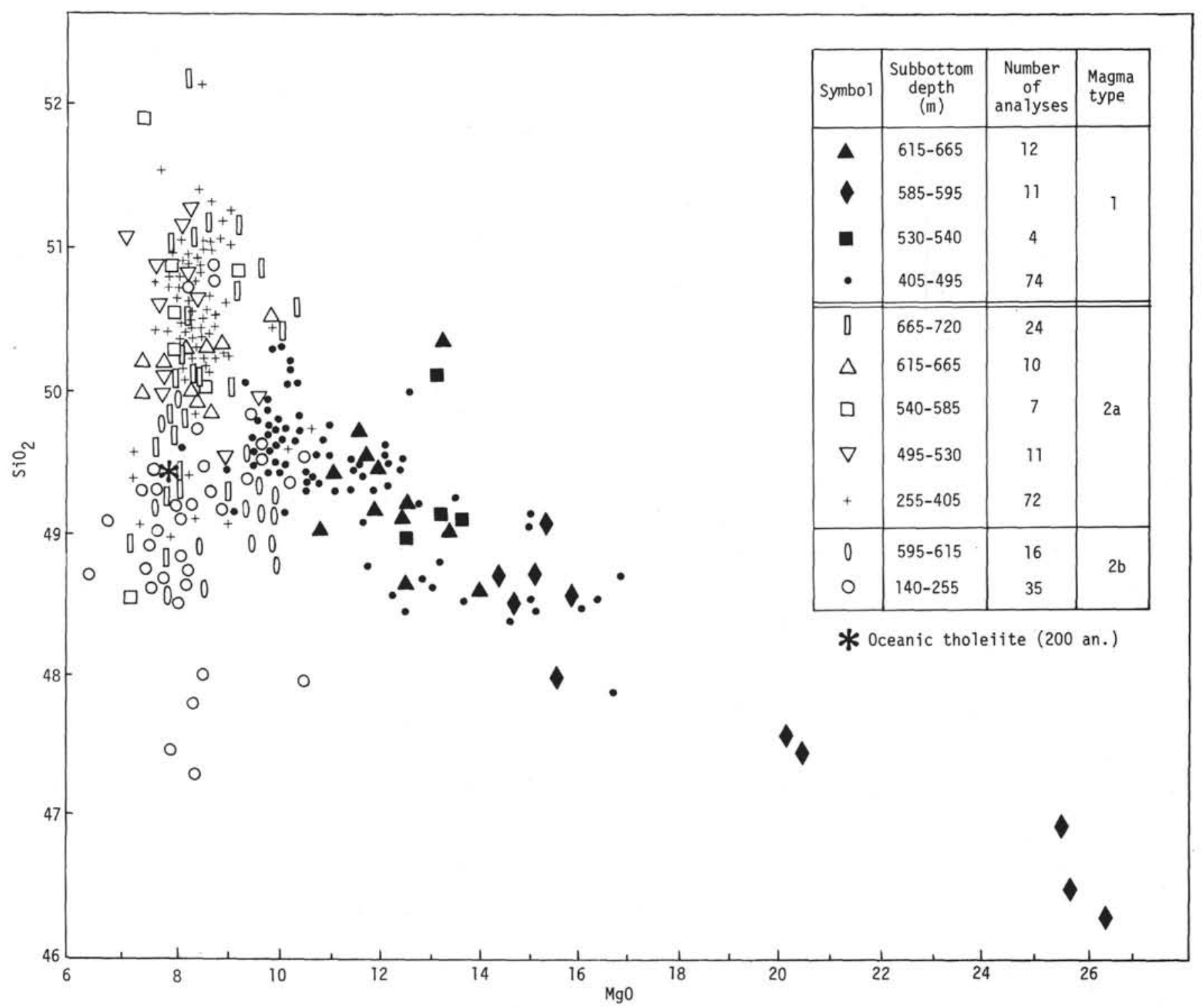

Figure 1a. Paired correlations between some major elements in basalts from Hole $332 B$.

high degree of tectonic activity in the area at the time of formation. Because of the tectonic instability, magmas moved rapidly to the surface rather than accumulating in large chambers where they would undergo extensive crystal fractionation. Most probably the observed differentiation in these magmas is due to crystallization of superheated magma during its rise to the surface and separation of crystals by flow processes.

In general, the thickness of lithologic units, the abundance of sedimentary interlayers, and the volume of magma erupted in a given cycle appears to increase upward in the section, suggesting that magmatic and tectonic activity in the area tapered off gradually rather than ending abruptly.

In Figure 3 basalts from Hole 332B are compared with basalts dredged from 67 stations along ridge crests in the Atlantic, Pacific, and Indian oceans (Sharaskin et al., in press) and with continental tholeiites (Manson, 1967). Compared to other oceanic basalts, those from
Hole 332B are distinctly lower in $\mathrm{TiO}_{2},(\mathrm{FeO})$, and $\mathrm{Na}_{2} \mathrm{O}$ and higher in $\mathrm{CaO}$ and $\mathrm{Al}_{2} \mathrm{O}_{3}$. Compared to continental olivine tholeiites, Hole 332B basalts are more uniform in composition and are lower in $(\mathrm{FeO})$ and $\mathrm{K}_{2} \mathrm{O}$ and higher in $\mathrm{CaO}$ and $\mathrm{Al}_{2} \mathrm{O}_{3}$. It is also apparent that some $332 \mathrm{~B}$ basalts are significantly enriched in $\mathrm{MgO}, \mathrm{CaO}$, and $\mathrm{Al}_{2} \mathrm{O}_{3}$, reflecting accumulation of olivine or plagioclase. It is interesting that the unusual character of these rocks is not reflected in the other oxides.

\section{PLUTONIC COMPLEX AT SITE 334}

The plutonic complex at Site 334 has been studied in detail because it may shed light on the composition and origin of oceanic Layer 3. Approximately 67 meters of interlayered gabbro, troctolite, and lherzolite were penetrated before the hole was terminated. The average chemical composition of each lithologic type is given in Table 1 (columns 2, 3, and 4). Columns 1 and 5 give 


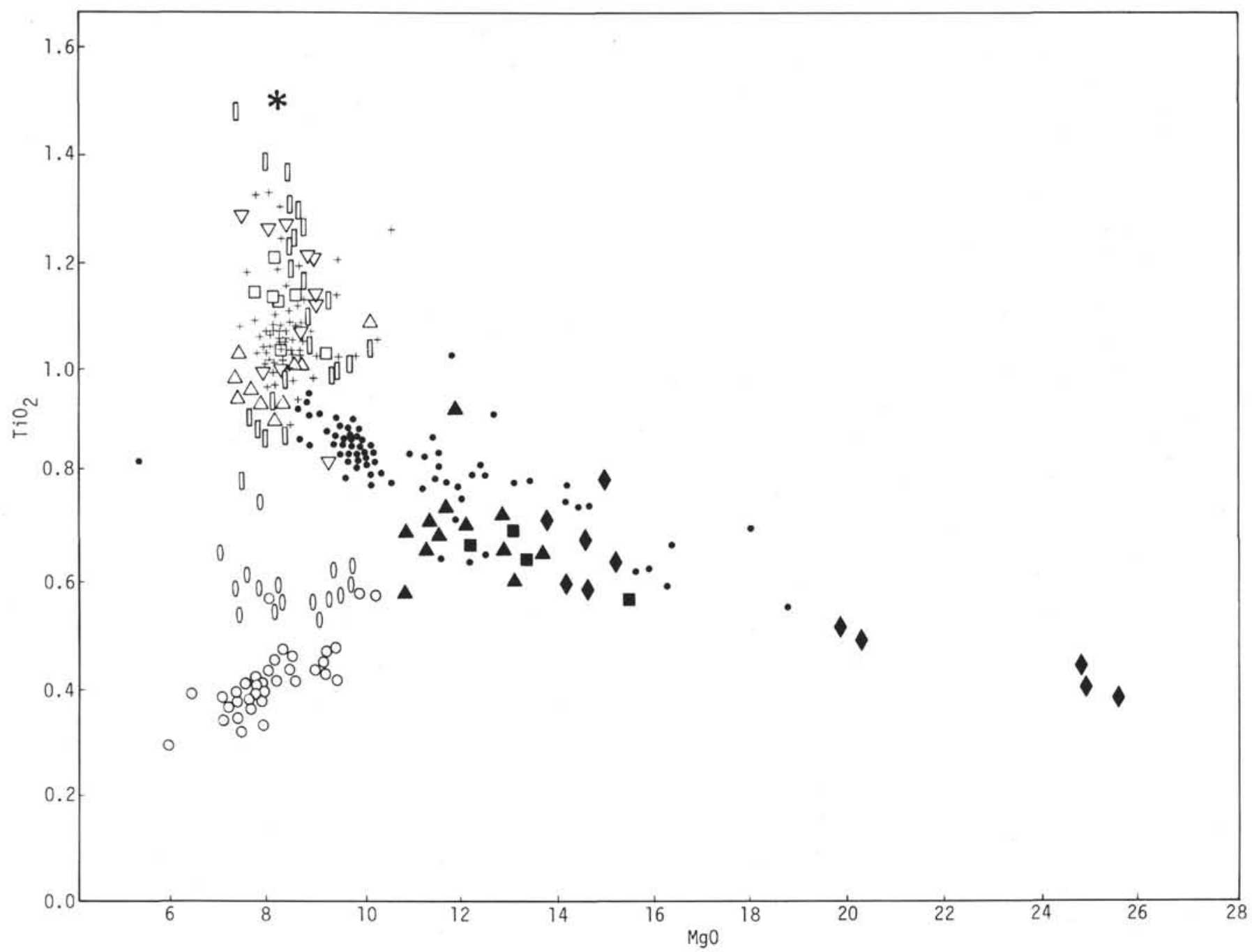

Figure 1b. Paired correlations between some major elements in basalts from Hole 332B. See Figure 1a for legend.

TABLE 1

Average Composition of Lherzolite, Troctolite, and Gabbro From Site 334 (wt \%)

\begin{tabular}{|c|c|c|c|c|c|c|c|c|c|c|}
\hline & \multicolumn{2}{|c|}{1} & \multicolumn{2}{|c|}{2} & \multicolumn{2}{|c|}{3} & \multicolumn{2}{|c|}{4} & \multicolumn{2}{|c|}{5} \\
\hline & $\bar{X}$ & $S$ & $\bar{X}$ & $S$ & $\bar{X}$ & $S$ & $\bar{X}$ & $S$ & $\bar{X}$ & $S$ \\
\hline $\mathrm{SiO}_{2}$ & 49.69 & 0.99 & 50.69 & 0.48 & 48.09 & 1.28 & 44.47 & 0.96 & 45.99 & 1.68 \\
\hline $\mathrm{TiO}_{2}$ & 1.48 & 0.47 & 0.42 & 0.43 & 0.07 & 0.01 & 0.06 & 0.01 & 0.16 & 0.10 \\
\hline $\mathrm{Al}_{2} \mathrm{O}_{3}$ & 15.67 & 1.55 & 16.22 & 1.34 & 10.14 & 2.06 & 4.90 & 0.64 & 3.47 & 1.58 \\
\hline $\mathrm{Fe}_{2} \mathrm{O}_{3}$ & 2.48 & 1.87 & & & & & & & 5.12 & 1.26 \\
\hline $\mathrm{FeO}$ & 8.05 & 0.41 & 7.28 & 2.74 & 6.76 & 0.74 & 9.10 & 0.86 & 3.81 & 1.50 \\
\hline $\mathrm{MnO}$ & 0.18 & 0.04 & 0.14 & 0.04 & 0.13 & 0.01 & 0.14 & 0.01 & 0.15 & 0.09 \\
\hline $\mathrm{MgO}$ & 7.97 & 1.09 & 9.81 & 1.77 & 22.80 & 3.45 & 37.19 & 2.29 & 38.63 & 3.12 \\
\hline $\mathrm{CaO}$ & 11.36 & 0.81 & 13.43 & 1.60 & 11.10 & 1.27 & 3.04 & 1.70 & 2.26 & 1.26 \\
\hline $\mathrm{Na}_{2} \mathrm{O}$ & 2.63 & 0.37 & 1.39 & 0.62 & 0.32 & 0.09 & 0.12 & 0.04 & 0.34 & 0.37 \\
\hline $\mathrm{K}_{2} \mathrm{O}$ & 0.23 & 0.14 & 0.11 & 0.10 & 0.04 & 0.02 & 0.03 & 0.02 & 0.07 & 0.06 \\
\hline
\end{tabular}

Note: 1 = Mid-oceanic ridge tholeiite (average of 200 analyses, Sharaskin et al., 2 = Gabbro from Site 334 ( 8 analyses); $3=$ Troctolite from Site 334 (8 analyses); $4=$ Plagioclase Lherzolite from Site 334 (12 analyses); $5=$ Lherzolite from mid-oceanic ridges (69 analyses, Dmitriev, et al., 1972); The sum in columns 2,3 , and 4 is less than $100 \%$ because $\mathrm{Fe}_{2} \mathrm{O}_{3}$ has been recalculated to $\mathrm{FeO}$. 


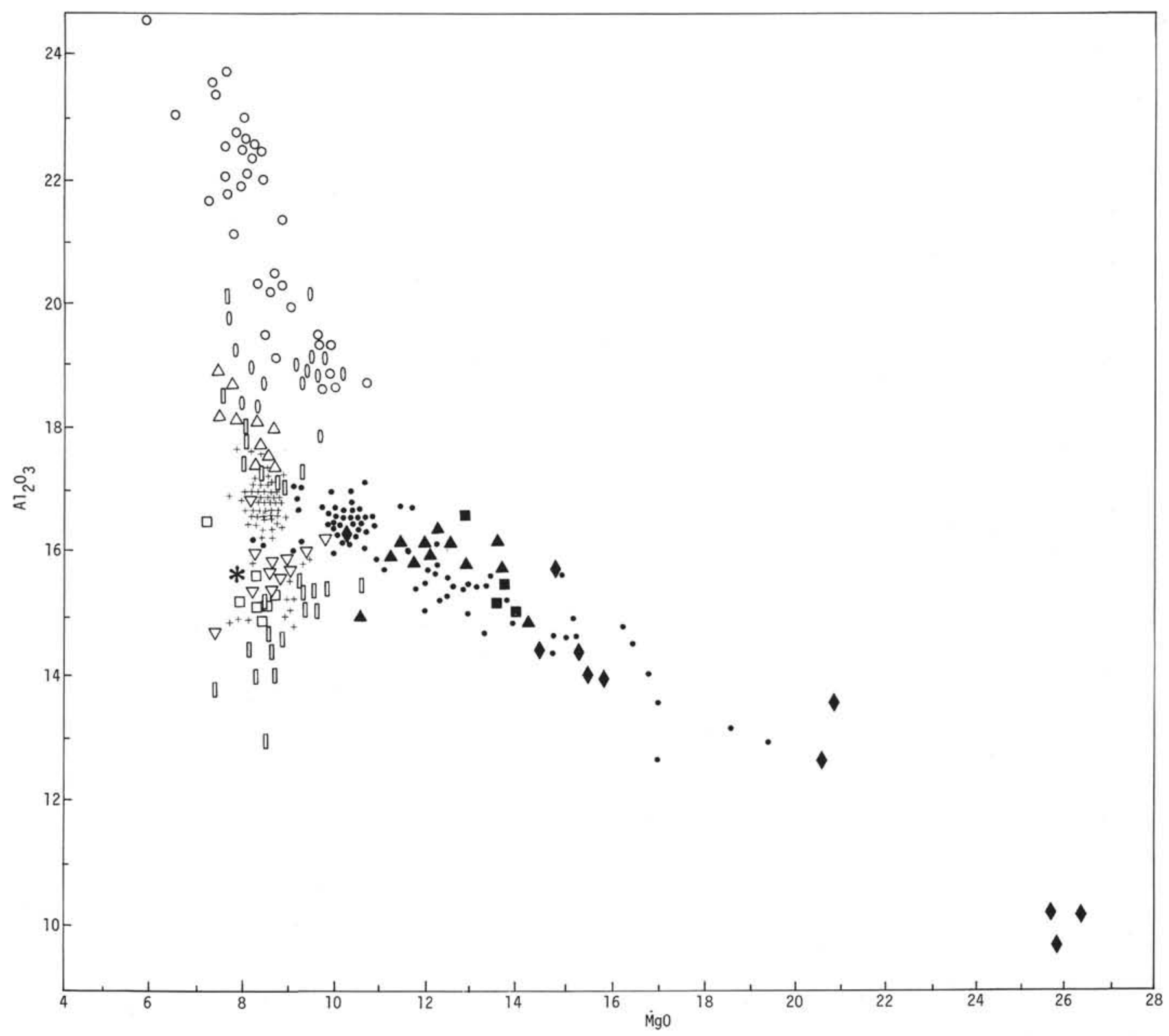

Figure 1c. Paired correlations between some major elements in basalts from Hole 332B. See Figure 1a for legend.

average analyses for oceanic tholeiite and oceanic lherzolite, respectively. Figure $4(\mathrm{a}, \mathrm{b})$ is a graphical comparison of the plutonic rocks to average oceanic tholeiites and lherzolites. It can be seen that Site 334 lherzolites are quite similar to average oceanic lherzolite but have somewhat lower concentrations of $\mathrm{SiO}_{2}$, $\mathrm{TiO}_{2}, \mathrm{Na}_{2} \mathrm{O}$, and $\mathrm{K}_{2} \mathrm{O}$ and higher $\mathrm{Al}_{2} \mathrm{O}_{3}$ and $\mathrm{CaO}$. Gabbro from Site 334 is compositionally similar to basalt from Hole 332B and has somewhat lower $(\mathrm{FeO}), \mathrm{TiO}_{2}$, $\mathrm{Na}_{2} \mathrm{O}$, and $\mathrm{K}_{2} \mathrm{O}$ and higher $\mathrm{Al}_{2} \mathrm{O}_{3}$ and $\mathrm{CaO}$ than the average oceanic tholeiite. These differences probably reflect regional differences in the ocean basins.

Troctolites are compositionally intermediate between gabbro and lherzolite, and one might conclude that all three rock types in this complex had a common origin.
However, the chemical relationship shown in Figure 4 and the range of composition of each type suggest that the troctolites are not related to the other rocks by a simple fractionation scheme. Formation of the troctolites probably required metasomatic transfer of $\mathrm{Na}_{2} \mathrm{O}, \mathrm{K}_{2} \mathrm{O}, \mathrm{TiO}_{2}, \mathrm{Al}_{2} \mathrm{O}_{3}$, and $\mathrm{CaO}$.

In Table 2 the average concentration of selected trace elements in gabbro, troctolite, and lherzolite from Site 334 are compared with concentrations in average oceanic tholeiite and lherzolite. Figure 4 shows that Site 334 troctolites are significantly enriched in $\mathrm{Au}, \mathrm{Cu}, \mathrm{Ba}$, and $\mathrm{Li}$ compared to the associated gabbros and lherzolites. These data confirm the conclusion that the troctolites were formed independently of gabbros in an open system. 


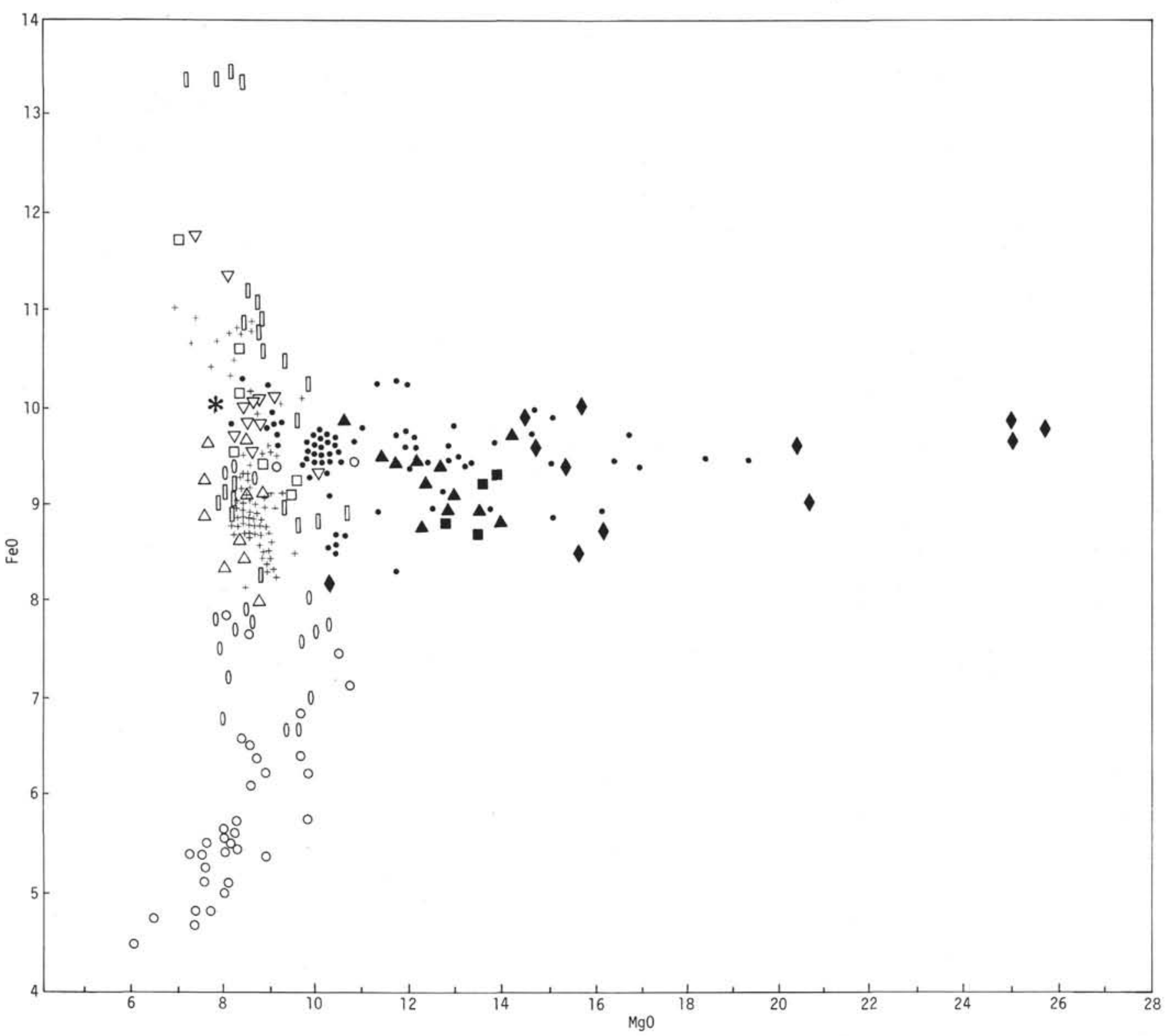

Figure 1d. Paired correlations between some major elements in basalts from Hole 332B. See Figure 1a for legend.

TABLE 2

Distribution of Some Trace Elements in Lherzolites, Troctolites, and Gabbro From Site 334 (all elements in ppm, Au-ppb)

\begin{tabular}{lcrrrr}
\hline & 1 & 2 & \multicolumn{1}{c}{3} & \multicolumn{1}{c}{4} & \multicolumn{1}{c}{5} \\
\hline $\mathrm{Cr}$ & $303(116)$ & $1031(8)$ & $1700(6)$ & $4800(5)$ & $4400(37)$ \\
$\mathrm{V}$ & $314(91)$ & $131(5)$ & $123(6)$ & $110(8)$ & $47(37)$ \\
$\mathrm{Ni}$ & $113(116)$ & $379(7)$ & $820(8)$ & $1844(12)$ & $2500(37)$ \\
$\mathrm{Co}$ & $42(87)$ & $66(7)$ & $62(6)$ & $96(9)$ & $117(37)$ \\
$\mathrm{Sr}$ & $130(100)$ & $14(7)$ & $10(7)$ & $5(9)$ & \\
$\mathrm{Ba}$ & $23(88)$ & $22(7)$ & $38(6)$ & $29(9)$ & $8(16)$ \\
$\mathrm{Li}$ & $5.6(32)$ & $5.0(5)$ & $8.0(4)$ & $6.1(4)$ & $4.1(37)$ \\
$\mathrm{Rb}$ & $1.6(43)$ & $2.0(5)$ & $2.3(8)$ & $2.1(9)$ & $0.5(37)$ \\
$\mathrm{Cu}$ & $97(94)$ & $86(8)$ & $107(7)$ & $45(12)$ & $40(37)$ \\
$\mathrm{Au}$ & $0.77(32)$ & $4.7(8)$ & $30.2(6)$ & $6.3(8)$ & $1.4(35)$ \\
\hline
\end{tabular}

Note: 1 = Mid-oceanic ridge tholeiite (Dmitriev et al., in press); 2 = Gabbro from Site $334 ; 3=$ Troctolite from Site 334; 4 = Plagioclase Lherzolites from Site $334 ; 5=$ Lherzolite from mid-oceanic ridges (Dmitriev et al., in press). Number of analyses is in parentheses. 


\section{DMITRIEV}

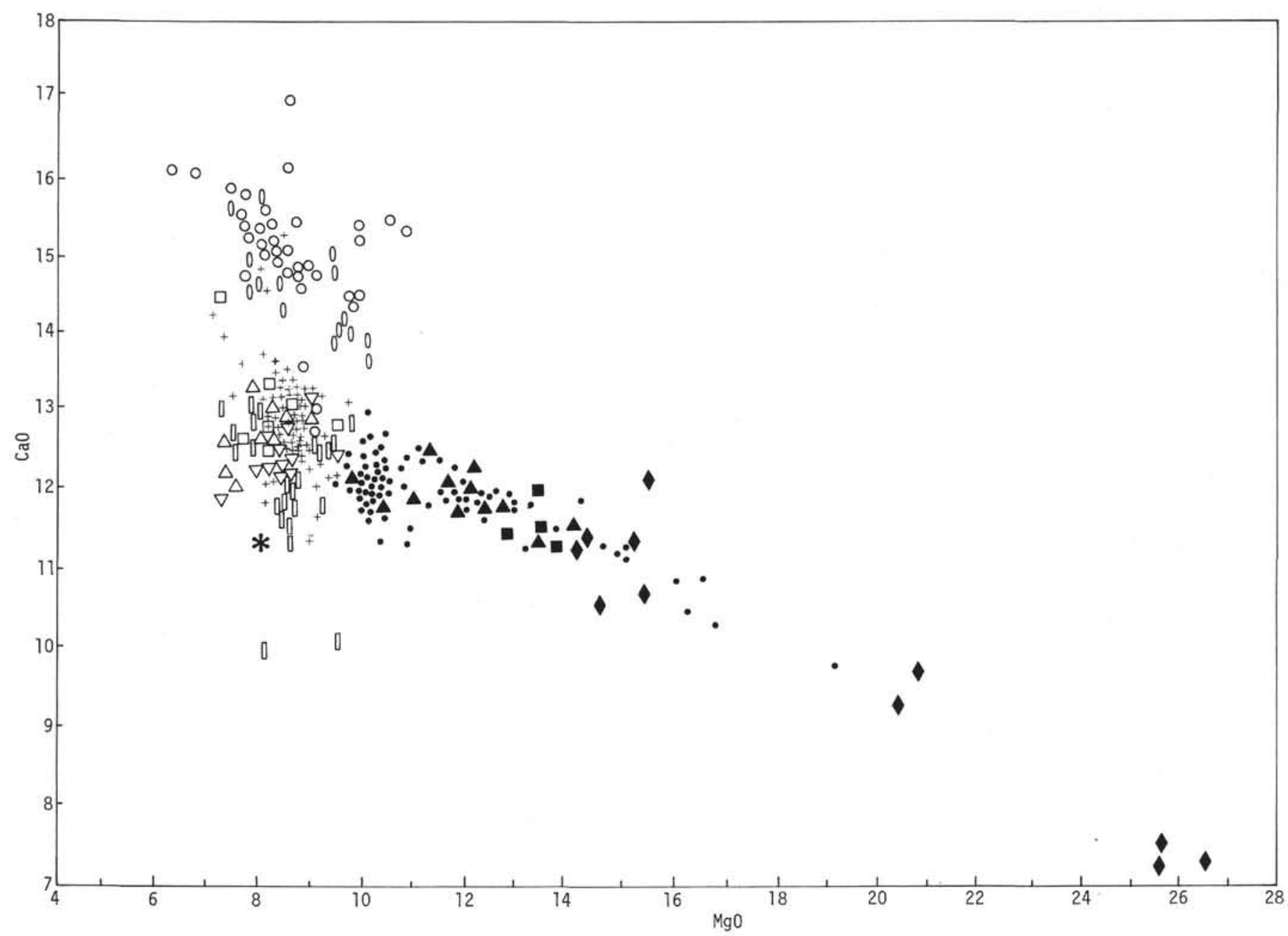

Figure 1e. Paired correlations between some major elements in basalts from Hole 332B. See Figure 1a for legend.

\section{REFERENCES}

Dmitriev, L., Ukhanov, A., and Sharaskin, A., 1972. Composition of the upper mantle: Geochimia, no. 10. (English translation in Geochem. International, v. 9, p. 781-792).
Manson, V., 1967. Geochemistry of basalts. In Hess, H., and Poldervaart, A. Ed., Basalts v. 1, New York (Interscience), in press.

Sharaskin, A., Charin, G., and Dmitriev, L., in press. Geochemistry of mid-ocean ridge basalts. 


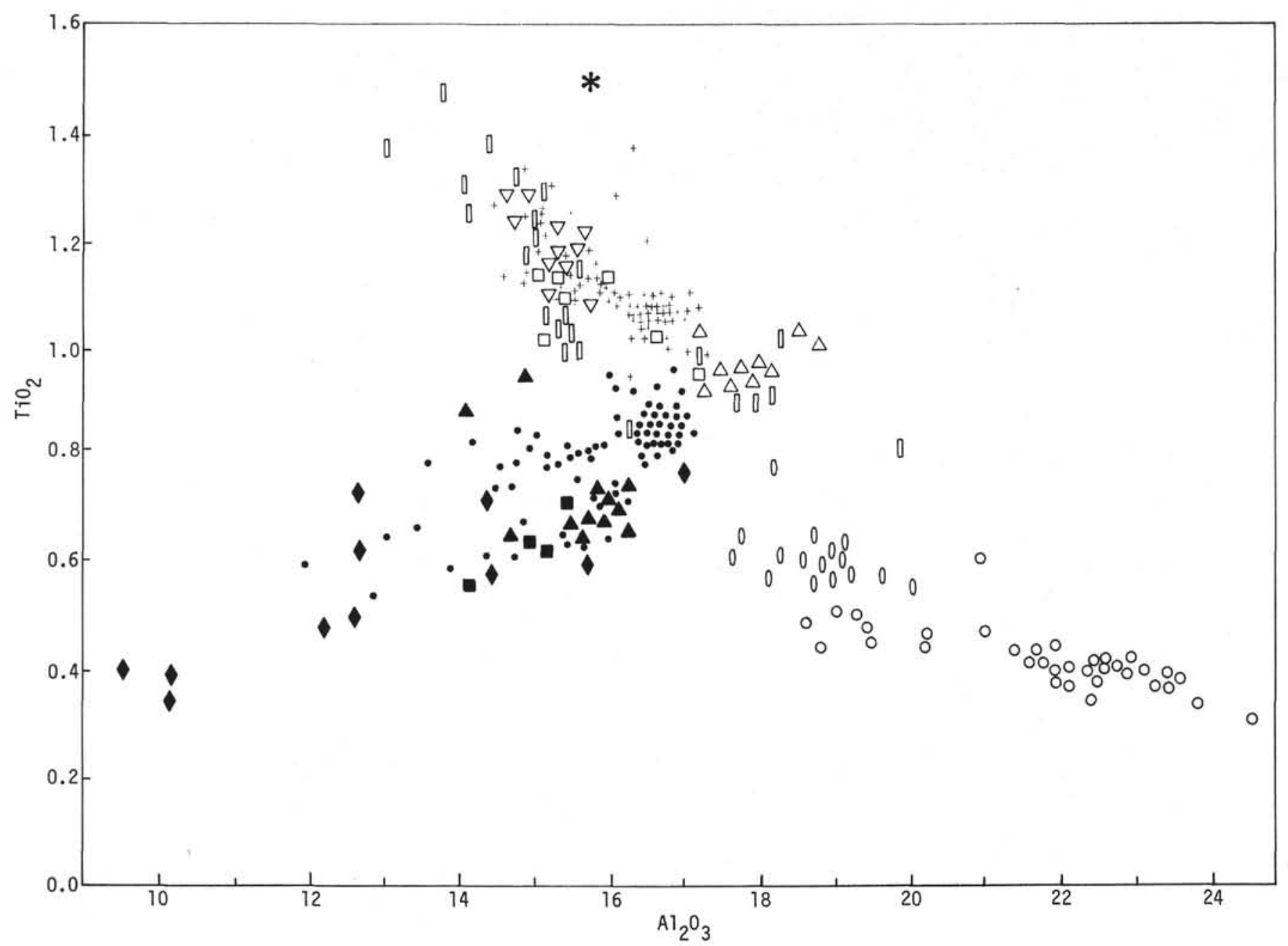

Figure 1f. Paired correlations between some major elements in basalts from Hole 332B. See Figure 1a for legend. 
L. DMITRIEV

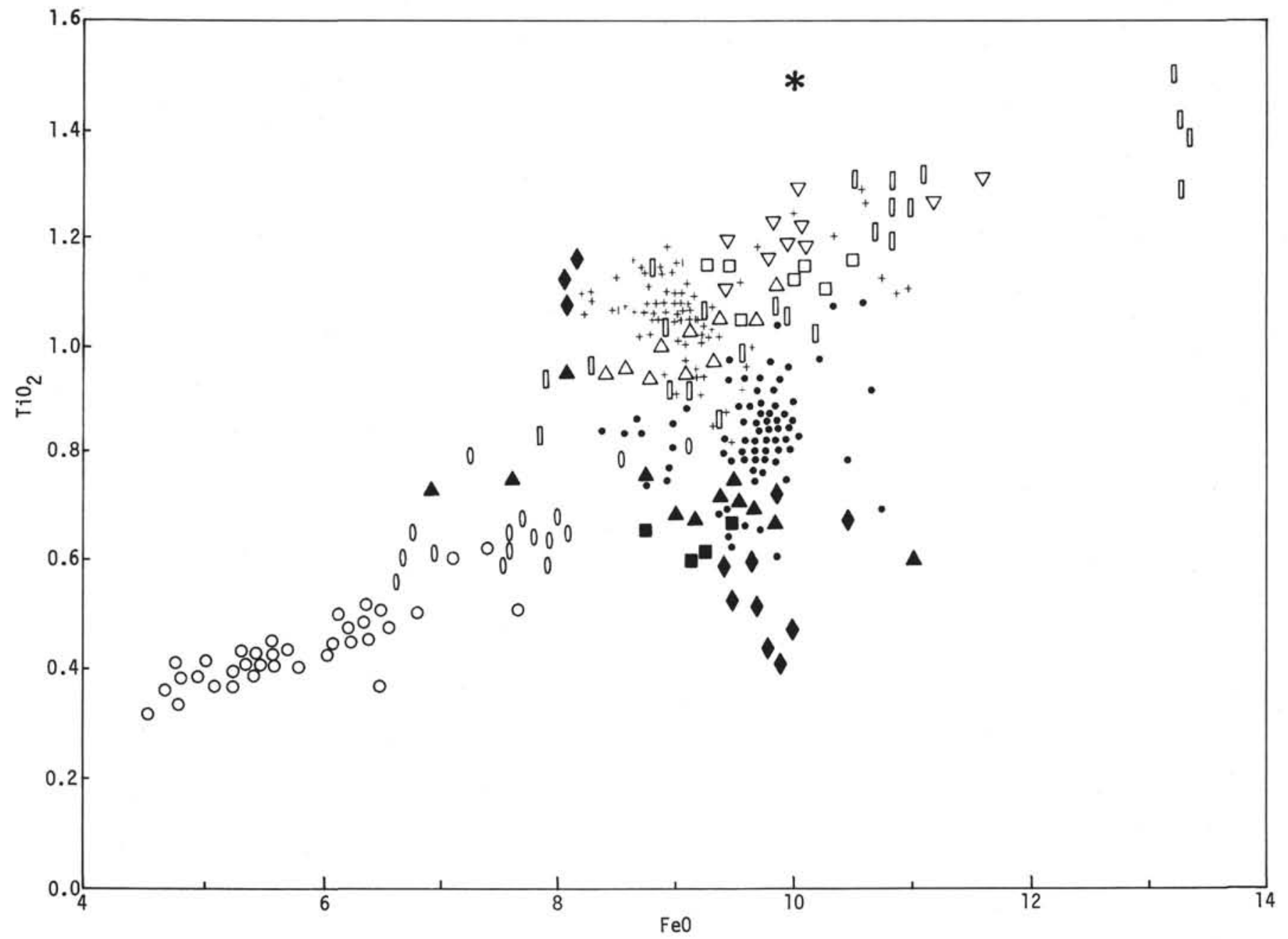

Figure 1g. Paired correlations between some major elements in basalts from Hole 332B. See Figure 1a for legend. 
PETROCHEMISTRY OF BASALTS AND PLUTONIC ROCKS

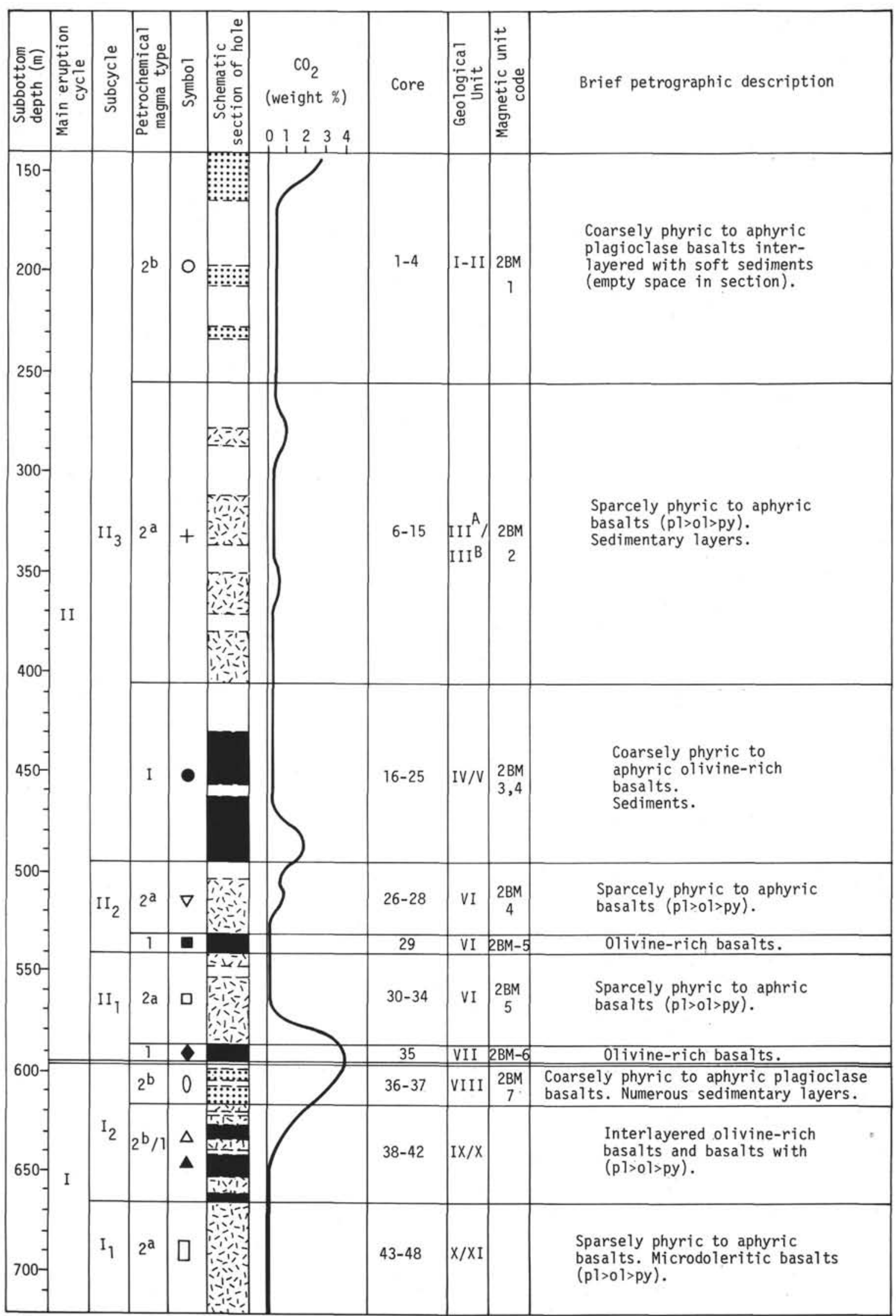

Figure 2. Schematic section of Hole $332 B$ showing the distribution of lithologic and chemical units. 

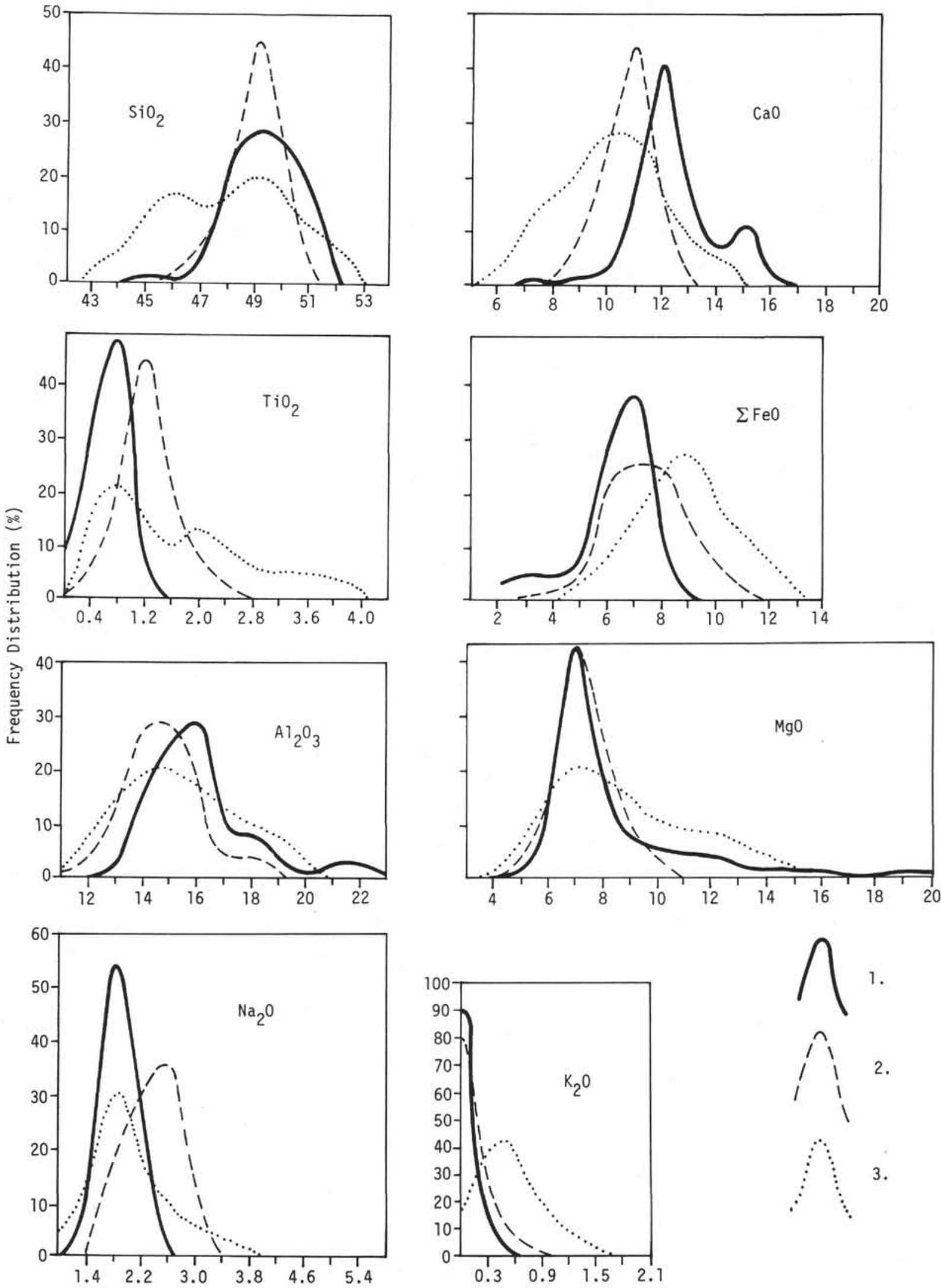

0xides (wt. \%)

Figure 3. Histograms of the major elements in oceanic and continental basalts. $1=$ Basalts from Hole 332B; $2=$ Mid-ocean ridge basalts (200 analyses) (Sharaskin et al., in press); $3=$ Continental olivine tholeiites (182 analyses) (Manson, 1967). 


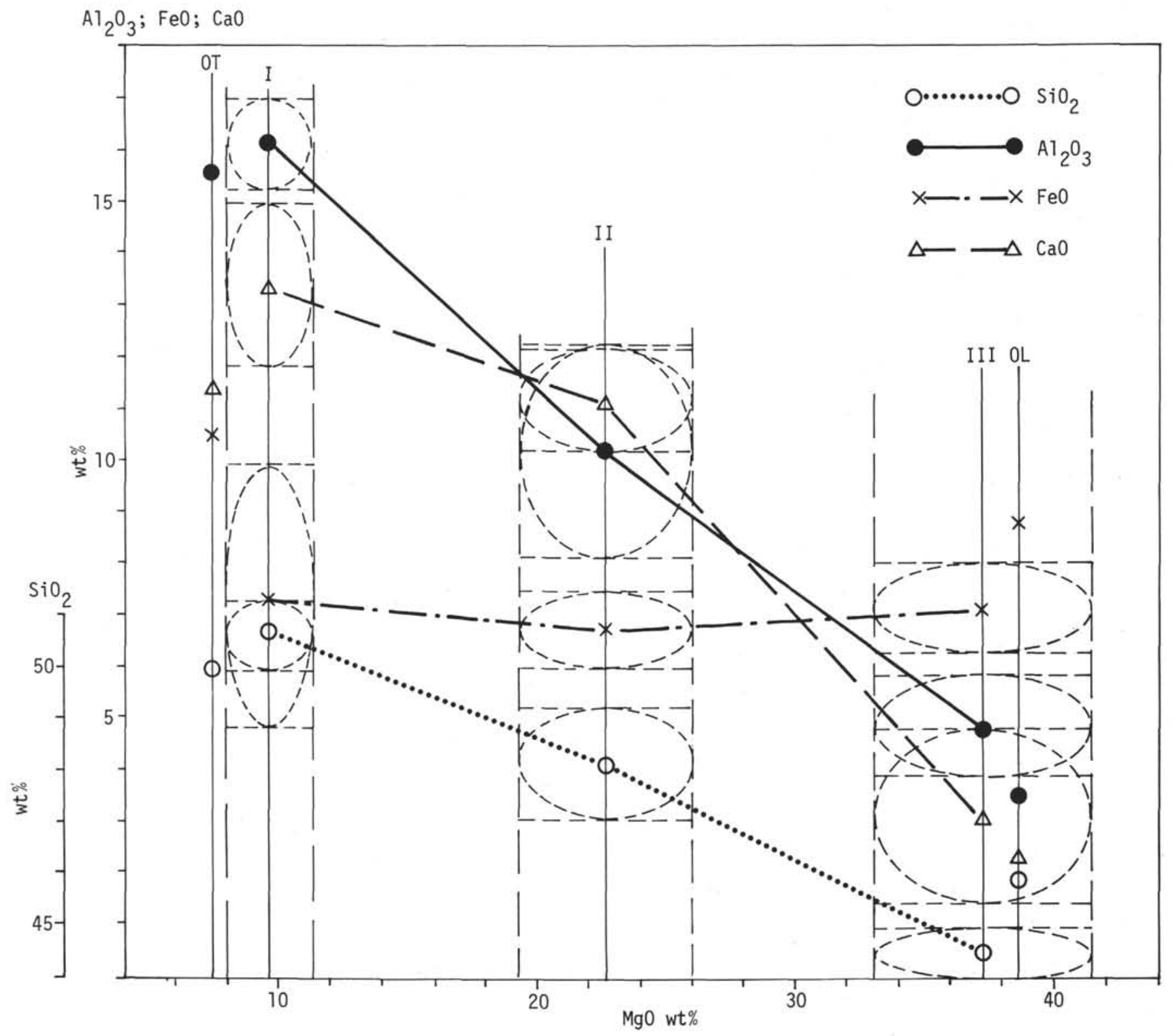

Figure 4a. Correlation between $\mathrm{MgO}$ and other major elements in basalts, gabbros, troctolites, and lherzolites. Data from Table 1. $I=$ Gabbro from Site 334; II = Trocolite from Site 334; III = Lherzolite from Site 334; OT = Average oceanic tholeite; $O L=$ Average oceanic lherzolite. Ovals show the standard deviation. 


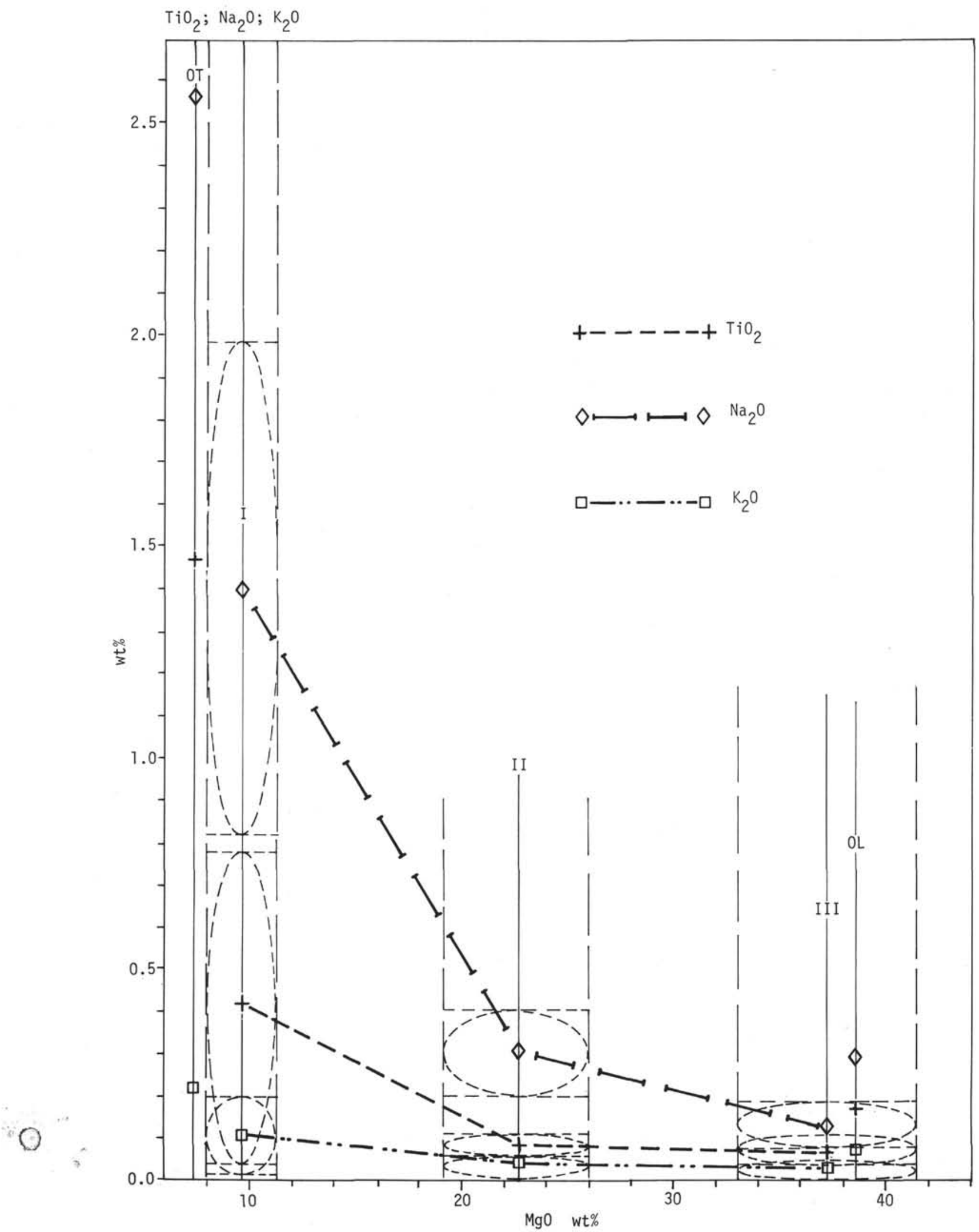

Figure $4 \mathrm{~b}$. Correlation between $\mathrm{MgO}$ and other major elements in basalts, gabbros, troctolites, and lherzolites. Data from Table 1. I = Gabbro from Site 334; II = Troctolite from Site 334; III = Lherzolite from Site 334; $O T=$ Average oceanic tholeiite; $O L=$ Average oceanic lherzolite. Ovals show the standard deviation. 


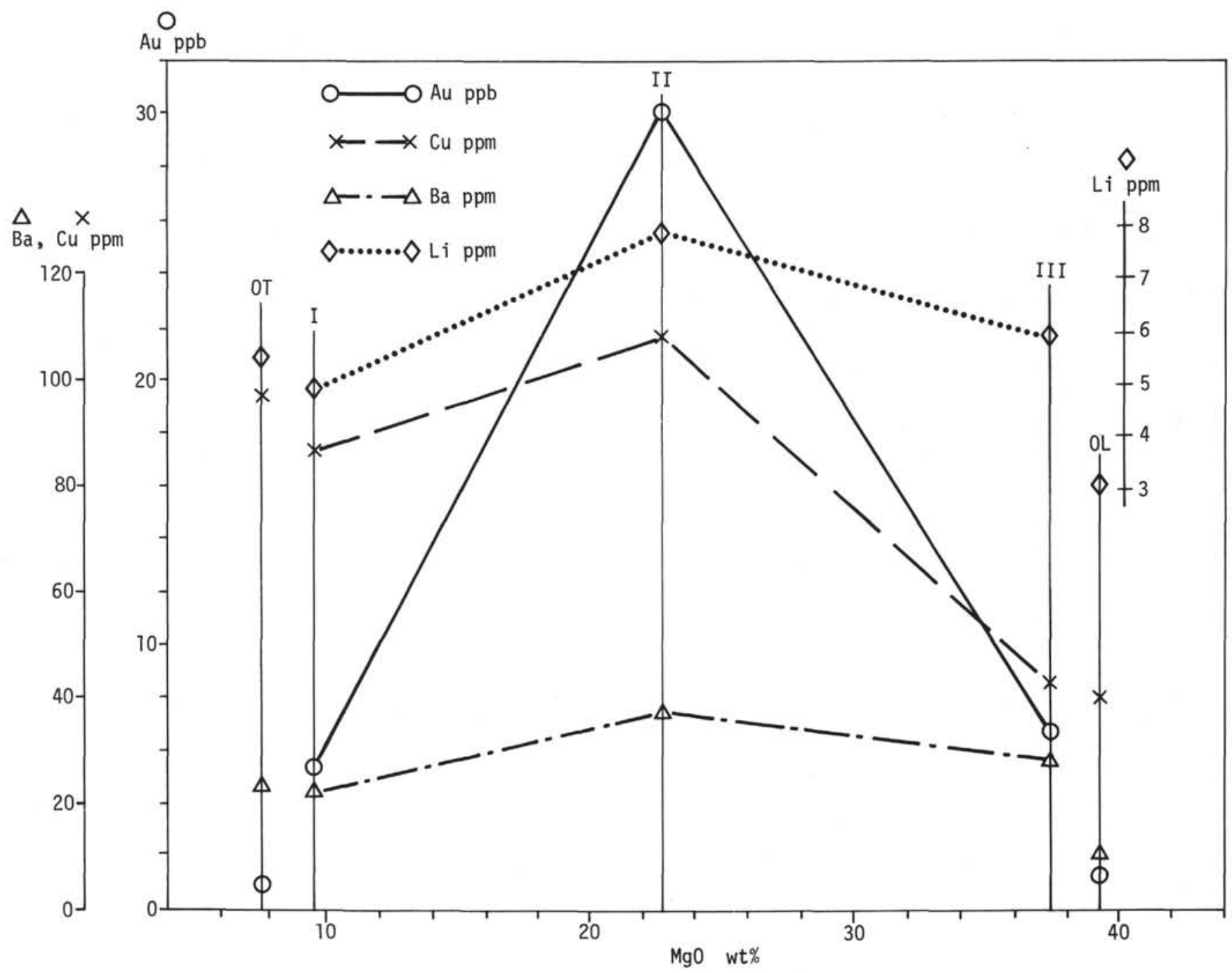

Figure 5. Correlation between $\mathrm{MgO}$ and some trace elements in basalts, gabbros, troctolites, and lherzolites. Data from Table 2. $I=$ Gabbro from Site 334; II = Troctolite from Site 334; III = Lherzolite from Site 334; OT = Average oceanic tholeiite; $O L=$ Average oceanic lherzolite. 